\title{
Neuropsychiatric manifestations of infective endocarditis: a study of 95 patients at Ibadan, Nigeria
}

\author{
O. BADEMOSI, ${ }^{1}$ A. O. FALASE, F. JAIYESIMI, AND A. BADEMOSI \\ From the Departments of Medicine and Paediatrics, University College Hospital, Ibadan, Nigeria
}

SYNOPSIS Thirty-eight percent of patients with infective endocarditis (36 of 95) had neuropsychiatric manifestations. In $75 \%$ (27 of 36), these features were the major presenting picture. Fifteen patients $(42 \%)$ presented with cerebrovascular lesions and seven $(19 \%)$ with meningitis. Toxic encephalopathy $(12.5 \%$ ) was not uncommon. Other neurological syndromes seen included psychosis and spinal cord lesions. The mortality was high especially when the infective endocarditis was acute in onset. It is essential to search diligently for an underlying cardiac cause in patients who present with neuropsychiatric symptoms because treatment of the underlying pathology improves prognosis.

Although the clinical features of infective endocarditis are well established, significant changes have taken place in the pattern of the disease in the developed countries over the last 20 years (Horder, 1909; Cates and Christie, 1951 ; Pankey, 1961, 1962; Thompson, 1964; Cooper et al., 1966; British Medical Journal, 1973). The few reports available on the pattern of the disease in Africans show significant differences from the present picture in the developed countries (Brockington and Edington, 1972; Somers et al., 1972; British Medical Journal, 1973; Falase et al., in preparation). Neurological complications which could be the presenting feature, are common and can mask the underlying infective endocarditis (Osler, 1885, 1909; Toone, 1941; Harrison and Hampton, 1967; Jones et al., 1969; Ziment, 1969; British Medical Journal, 1970). This report describes the neuropsychiatric manifestations in a series of patients with infective endocarditis seen at the University College Hospital (UCH), Ibadan between 1962 and 1973.

\section{METHODS}

The data analysed were obtained from hospital cases and necropsy records of patients. The diagnosis of infective endocarditis was based on the following

1 Address for reprints: Dr O. Bademosi, Neurology Unit, Department of Medicine, U.C.H., Ibadan, Nigeria.

(Accepted 3 December 1975.) criteria: (1) repeated positive blood cultures during a febrile illness in a patient with known previous valvular or congenital heart disease; (2) evidence of peripheral manifestations of infective endocarditis; (3) development of a significant cardiac murmur with features of cardiac failure in any patient admitted for an unexplained febrile illness while under observation; (4) favourable response to antibiotic therapy despite negative blood cultures when criteria 2 and 3 above were satisfied; (5) necropsy findings.

The endocarditis was subdivided into: acute when there was severe toxaemia, rapid deterioration, and the infection was caused by a virulent pathogen; subacute when there was little or no toxaemia, a prolonged clinical course, and the infection was caused by a less virulent pathogen. Diagnosis at necropsy was accepted only if there were unequivocal evidence of infective endocarditis.

\section{RESULTS}

A total of 95 patients with infective endocarditis was available for review. Thirty-six of these patients $(38 \%)$ had a neurological problem and this was the first presenting feature of the disease in 27. Thirty of the patients with neurological complications $(83 \%)$ died and a necropsy was performed in 27 of them; neuropathological descriptions were available, however, in only 21 of these patients.

The age and sex distribution of the patients with neurological complications are shown in 
TABLE 1

AGE AND SEX DISTRIBUTION IN INFECTIVE ENDOCARDITIS PATIENTS WITH NEUROLOGICAL MANIFESTATIONS

\begin{tabular}{lcccc}
\hline \multirow{2}{*}{ Age $(y r)$} & \multicolumn{2}{c}{ Sex } & Total & Percentage \\
\cline { 2 - 3 } & Male & Female & & \\
\hline Under 10 & - & 1 & 1 & 2.8 \\
$10-19$ & 4 & 2 & 6 & 16.7 \\
$20-29$ & 4 & 10 & 14 & 38.8 \\
$30-39$ & 1 & 3 & 4 & 11.1 \\
$40-49$ & 4 & 2 & 6 & 16.7 \\
50 and over & 4 & 1 & 5 & 13.9 \\
\hline Total & 17 & 19 & 36 & 100.0 \\
\hline Percentage & 47.0 & 53.0 & 100.0 & \\
\hline
\end{tabular}

Table 1. There was no appreciable sex bias. The peak incidence was between 20 and 29 years and $60 \%$ of the patients were under 40 years old.

NEUROPSYCHIATRIC MANIFESTATIONS The pattern of the neuropsychiatric symptoms encountered is shown in Table 2.

TABLE 2

FREQUENCY OF NEUROPSYCHIATRIC SYMPTOMS IN 95 PATIENTS WITH INFECTIVE ENDOCARDITIS

\begin{tabular}{lcc}
\hline Symptom & Number & Percentage \\
\hline Stroke & 15 & 15.7 \\
Toxic & $12^{*}$ & 12.5 \\
Meningo-encephalitic & 7 & 7.4 \\
Psychiatric & 2 & 2.1 \\
Dyskinesia & - & 0.0 \\
\hline Total number of patients with & & \\
$\quad$ neurological complications & 36 & 38.0 \\
\hline
\end{tabular}

* Including one patient admitted because of fever and confusional state who became paraplegic under supervision.

Stroke $(15.7 \%)$ was the most frequent presentation. The clinical picture was commonly a hemiparesis with speech disturbance (dysarthria or dysphasia). There was associated loss of consciousness in two-thirds of the patients. One patient presented with sudden onset of coma without any prodromal or premonitory symptoms.
Toxic symptoms (headache, lethargy, dizziness, drowsiness) were present in 12 patients $(12.5 \%)$ and accounted for the presenting features in eight of them. Headache, which was the commonest complaint, was observed in 11 of the 12 patients.

Seven patients $(7.4 \%)$ were presumed to have meningitis on admission, pneumococcal meningitis being confirmed in four of them. In two patients, the CSF had a polymorphonuclear cellular reaction, an elevated protein content (0.8 and $1.1 \mathrm{~g} / 1$ respectively) but grew no organisms on culture. In all the seven patients, the underlying infective endocarditis was diagnosed only at necropsy.

In two patients, psychiatric symptoms were the cause for admission. The clinical details of one of the patients are briefly summarized below.

\section{CASE HISTORY}

A 33 year old woman suddenly became aggressive and quarrelsome two weeks after delivery of a fullterm still-born child. She was noticed to laugh inappropriately. She had lost social inhibitions, toying with her soiled bedclothes. There was no antenatal supervision of the pregnancy. On examination, she was pale and febrile (oral temperature $39.45^{\circ} \mathrm{C}$ $\left(103^{\circ} \mathrm{F}\right)$ ); signs of consolidation were present in the lower lobes of both lungs and the heart was enlarged. There were no localizing neurological signs. She was treated with massive doses of intravenous crystalline penicillin but died within 12 hours of admission. Postmortem examination revealed a large patent foramen ovale, infective endocarditis on a distorted tricuspid valve, and infarcts in the spleen and kidneys. The brain showed slight asymmetry only (left hemisphere bigger than the right), and the meninges were thickened.

Spinal cord and peripheral nerve lesions including isolated cranial nerves were uncommon. Only one patient was presumed to have spinal cord involvement, and the recovery after adequate treatment was dramatic and complete.

PATHOLOGICAL FEATURES When the endocarditis was acute, all patients with neurological complications died (Table 3 ). The overall mortality of $83.3 \%$ in patients with neurological complications is higher than in patients without $(70 \%)$. The neuropathological findings are shown in Table 4. Evidence of pneumococcal meningitis 
TABLE 3

PROGNOSIS ACCORDING TO THE TYPE OF ENDOCARDITIS IN 36 PATIENTS WITH NEUROLOGICAL MANIFESTATIONS

\begin{tabular}{|c|c|c|c|}
\hline \multirow{2}{*}{$\begin{array}{l}\text { Type of } \\
\text { lesion }\end{array}$} & \multicolumn{2}{|c|}{ Prognosis } & \multirow{2}{*}{$\begin{array}{c}\text { Case } \\
\text { fatality rate } \\
(\%)\end{array}$} \\
\hline & $\begin{array}{c}\text { Number of } \\
\text { patients }\end{array}$ & Died & \\
\hline $\begin{array}{l}\text { Acute } \\
\text { Subacute }\end{array}$ & $\begin{array}{l}16 \\
20\end{array}$ & $\begin{array}{l}16 \\
14\end{array}$ & $\begin{array}{r}100.0 \\
70.0\end{array}$ \\
\hline Total & 36 & 30 & 83.3 \\
\hline
\end{tabular}

was present in four patients; in two other patients, the meninges showed congestion of the vessels only. In one patient, multiple cerebral abscesses were found associated with evidence of extensive septic emboli from Staphylococcus aureus endocarditis involving the mitral and tricuspid valves. Embolic occlusion of the middle cerebral artery was present in three patients and thrombosis of the same vessel in one patient. A mycotic aneurysm was present in only
TABLE 4

NEUROPATHOLOGICAL FINDINGS IN 21 NECROPSY CASES WITH INFECTIVE ENDOCARDITIS

\begin{tabular}{lcc}
\hline Lesion & Number & Percentage \\
\hline Meningitis & $6^{*}$ & 29.0 \\
Cerebral & & \\
$\quad$ Haemorrhage & $5 \dagger$ & 24.0 \\
Oedema & 3 & 13.0 \\
$\quad$ Infarct & 1 & 5.0 \\
Abscess & 1 & 5.0 \\
Occlusion of cerebral vessel & & 19.0 \\
$\quad$ (emboli, thrombosis) & 4 & 5.0 \\
Mycotic aneurysm & 1 & 100.0 \\
\hline Total & 21 &
\end{tabular}

* Including two cases with congestion of the meninges only.

+ Including one case with a small cerebellar haemorrhage.

one patient; it arose from a branch of the middle cerebral artery and had ruptured into the brain with extension into both the ventricles and subarachnoid space.

Table 5 shows the pattern of valvular involve-

TABLE 5

PATTERN OF VALVULAR INVOLVEMENT AT NECROPSY IN PATIENTS WITH NEUROLOGICAL COMPLICATIONS ACCORDING TO TYPE OF INFECTIVE ENDOCARDITIS

\begin{tabular}{|c|c|c|c|c|c|c|c|c|}
\hline \multirow{2}{*}{$\begin{array}{c}\text { Type of } \\
\text { endocarditis }\end{array}$} & \multicolumn{7}{|c|}{ Valve(s) involved } & \multirow{2}{*}{$\begin{array}{c}\text { Number } \\
\text { of } \\
\text { patients }\end{array}$} \\
\hline & Tricuspid & Aortic & Mitral & $\begin{array}{c}\text { Tricuspid } \\
\text { and } \\
\text { mitral }\end{array}$ & $\begin{array}{c}\text { Tricuspid } \\
\text { and } \\
\text { aortic }\end{array}$ & $\begin{array}{l}\text { Mitral } \\
\text { and } \\
\text { aortic }\end{array}$ & $\begin{array}{c}\text { All } \\
\text { three } \\
\text { valves }\end{array}$ & \\
\hline $\begin{array}{l}\text { Acute } \\
\text { Subacute }\end{array}$ & $\frac{3 *}{-}$ & $\begin{array}{l}5 \\
1\end{array}$ & $\begin{array}{l}3 \\
7\end{array}$ & 2 & 1 & $\begin{array}{l}2 \\
3\end{array}$ & - & $\begin{array}{l}16 \\
11\end{array}$ \\
\hline Total & $3^{*}$ & 6 & 10 & 2 & 1 & 5 & - & 27 \\
\hline
\end{tabular}

* Including one patient with vegetation on the endocardium of right ventricle.

TABLE 6

ORGANISM ISOLATED IN PATIENTS WITH NEUROLOGICAL COMPLICATIONS ACCORDING TO TYPE OF INFECTIVE ENDOCARDITIS

\begin{tabular}{|c|c|c|c|c|c|c|c|c|}
\hline & \multirow{2}{*}{$\begin{array}{l}\text { Pneumo- } \\
\text { coccus }\end{array}$} & \multicolumn{3}{|c|}{ Staphylococcus } & \multicolumn{2}{|c|}{ Streptococcus } & \multirow{2}{*}{$\begin{array}{c}\text { Gram-ve } \\
\text { bacilli } \\
\text { or } \\
\text { Salmonella }\end{array}$} & \multirow{2}{*}{$\begin{array}{l}\text { Number } \\
\text { of } \\
\text { patients }\end{array}$} \\
\hline & & pyogenes & aureus & $\begin{array}{c}\text { sapro- } \\
\text { phyticus }\end{array}$ & $\begin{array}{c}\text { non- } \\
\text { haemolytic }\end{array}$ & $\begin{array}{l}\text { Fae- } \\
\text { calis }\end{array}$ & & \\
\hline $\begin{array}{l}\text { Acute } \\
\text { Subacute }\end{array}$ & $\underline{3}$ & $\frac{2}{-}$ & $\underline{2}$ & $\overline{2}$ & $\overline{1}$ & $\overline{2}$ & $\overline{2}$ & $\begin{array}{l}7 \\
5^{*}\end{array}$ \\
\hline Total & 3 & 2 & 2 & 2 & 1 & 2 & 2 & 12 \\
\hline
\end{tabular}

* Mixed organisms were isolated in three patients. 
ment at necropsy in these patients. The mitral valve was the most frequent single valve affected. Involvement of more than one valve was common but in no patient were all the valves involved. The tricuspid valve was involved only in patients with acute endocarditis.

The organisms isolated according to the type of endocarditis are shown in Table 6. Positive blood cultures were obtained in $12(33 \%)$ of the patients with neurological complications. Pneumococcus and Staphylococcus pyogenes and aureus were encountered only in patients with acute endocarditis. Mixed infections were seen only in patients with a subacute illness.

\section{DISCUSSION}

Neurological complications occurred in $38 \%$ of the patients with infective endocarditis in this study. This finding is in keeping with the incidence of 15 to $40 \%$ reported by previous authors, which suggests that neuropsychiatric complications are common in infective endocarditis (Toone, 1941; Pankey, 1961, 1962; Harrison and Hampton, 1967; Jones et al., 1969). The relatively younger age of the patients in this study is in keeping with the pattern of the disease in Africans (Somers et al., 1972; Falase et al., in preparation), unlike the experience in the developed countries (Thompson, 1964; Cooper et al., 1966).

The spectrum of neuropsychiatric symptoms seen in this study is similar to that described by other workers (Harrison and Hampton, 1967; Jones et al., 1969). Coma as a presenting feature is uncommon; it could be caused by cerebral infarction after an embolus or from haemorrhage due to rupture of a mycotic aneurysm into the brain substance or subarachnoid space. Although the meningeal signs in our patient who was admitted with sudden onset of coma suggested haemorrhage into the subarachnoid space, the appearance of a focal neurological deficit and its subsequent resolution favoured an embolic phenomenon. Toxic encephalopathy has been related to miliary cerebral abscesses and infarcts (Bruetsch, 1939) but neither of these lesions was seen in patients with psychotic and toxic features in this study. It is conceivable that these features were due solely to the associated toxaemia. Isolated cranial nerve involvement and extra- pyramidal syndromes were absent in this series. This could be due to the rather short clinical course of the patients or lack of clinical awareness. Mycotic aneurysms are usually asymptomatic unless rupture occurs and this could account for the observed low incidence in this study (Cantu et al., 1966; Ziment and Johnson, 1968). Conceivably, it may be related to the rarity of intracranial aneurysms in the African (Odeku, 1968; Adeloye et al., 1970).

The rather low incidence of positive blood cultures in this study conforms to the overall experience of infective endocarditis in Africans (Somers et al., 1972; Falase et al., in preparation), and the high failure rate could be related to factors such as poor bacteriological and culture techniques or previous antibiotic therapy (British Medical Journal, 1973). Pneumococcal endocarditis may be complicated by meningitis (Austrian, 1957), and the latter carries with it a higher mortality rate in Nigerians (Lucas, 1964; Bademosi and Osuntokun, 1976). It is conceivable that failure to recognize and treat underlying endocarditis is a major factor in the high mortality of pneumococcal meningitis in this environment.

Rheumatic valvular disease was the most common pre-existing lesion and the preponderance of mitral valve involvement in this study no doubt reflects the pattern of valvular lesions encountered in rheumatic heart disease in the Africans (Somers et al., 1972; Falase et al., in preparation). The preponderance of left-sided cardiac valvular lesions in this study is in agreement with the teaching that emboli in the systemic circulation are commonly derived from the left side of the heart (Cappell, 1968). The paradoxical embolic phenomenon was rare in this study; infective endocarditis involving the right side of heart was limited to patients with an acute illness and may be solely a feature of septicaemia caused by virulent organisms.

Prognosis was worse in patients with acute endocarditis and this is in agreement with those in previous studies (Cates and Christie, 1951; Morgan and Bland, 1959; Pankey, 1962). The high mortality could be related to the neurological complications themselves or to the severe toxaemia associated with acute endocarditis. It might, however, be related to lack of clinical awareness and failure to institute effective treat- 
ment early. No doubt, the prognosis of the disease would improve with earlier investigation and more accurate diagnosis and prompt institution of therapy. The detection of the cardiac origin of these neuropsychiatric manifestations is particularly important now that effective treatment is available, although the incidence of neurological complications of infective endocarditis is said not to have changed (British Medical Journal, 1973).

\section{REFERENCES}

Adeloye, A., Osuntokun, B. O., and Odeku, E. L. (1970). Spontaneous subarachnoid haemorrhage in Nigerians. Tropical and Geographical Medicine, 22, 20-29.

Austrian, R. (1957). Pneumococcal endocarditis, meningitis and rupture of the aortic valve. Archives of Internal Medicine, 99, 539-544.

Bademosi, O., and Osuntokun, B. O. (1976). The clinical spectrum of pyogenic meningitis in Southern Nigeria 19621973. Degenerative Disorders in the African Environment: Epidermiology and Consequences. Proceedings of the 1975 Annual Scientific Conference of the East African Medical Research Council. (In press.)

British Medical Journal (1970). Neurological complications of infective endocarditis. British Medical Journal, 2, 619.

British Medical Journal (1973). Infective endocarditis. British Medical Journal, 4, 121.

Brockington, I. F., and Edington, G. M. (1972). Adult endocarditis in Western Nigeria: a clinico-pathological synopsis. American Heart Journal, 83, 27-40.

Bruetsch, W. L. (1939). The histopathology of the psychosis with subacute bacterial and chronic verrucose rheumatic endocarditis. American Journal of Psychiatry, 95, 335-346.

Cantu, R. C., LeMay, M., and Wilkinson, H. A. (1966). The importance of repeated angiography in the treatment of mycotic-embolic intracranial aneurysms. Journal of Neurosurgery, 25, 189-193.

Cappell, D. F. (1968). Muir's Textbook of Pathology, 8th edn, p. 75. Arnold: London.
Cates, J. E., and Christie, R. V. (1951). Subacute bacterial endocarditis: a review of 442 patients. Quarterly Journal of Medicine, 20, 93-130.

Cooper, E. S., Cooper, J. W., and Schnabel, T. G. (1966). Pitfalls in the diagnosis of bacterial endocarditis. Archives of Internal Medicine, 118, 55-61.

Harrison, M. J. G., and Hampton, J. R. (1967). Neurological presentation of bacterial endocarditis. British Medical Journal, 2, 148-151.

Horder, T. J. (1909). Infective endocarditis, with an analysis of 150 cases and with special reference to the chronic form of the disease. Quarterly Journal of Medicine, 2, 289-324.

Jones, H. R., Sikert, R. G., and Garaci, J. E. (1969). Neurologic manifestations of bacterial endocarditis. Annals of Internal Medicine, 71, 21-28.

Lucas, A. O. (1964). Pneumococcal Meningitis in Nigerian Adults. Thesis: Newcastle-upon-Tyne.

Morgan, W. L., and Bland, E. F. (1909). Bacterial endocarditis in the antibiotic era. Circulation, 19, 753-765.

Odeku, E. L. (1968). Intracranial vascular anomalies in Nigerians. Journal of the National Medicine Association, 60, 173-180.

Osler, W. (1885). Goulstonian Lectures on malignant endocarditis. Lancet, 1, 415-418, 459-464, 505-508.

Osler, W. (1909). Chronic infective endocarditis. Quarterly Journal of Medicine, 2, 219-230.

Pankey, G. A. (1961). Subacute bacterial endocarditis at University of Minnesota Hospitals, 1939-1959. Annals of Internal Medicine, 55, 550-561.

Pankey, G. A. (1962). Acute bacterial endocarditis at University of Minnesota Hospitals, 1939-1959. American Heart Journal, 64, 583-591.

Somers, K., Patel, A. K., D'Arbela, P. G., and Hunt, M. S. R. (1972). Infective endocarditis: an African experience. British Heart Journal, 34, 1107-1112.

Thompson, J. W. (1964). Endocarditis as a cause of cerebrovascular lesions. British Medical Journal, 2, 1132.

Toone, E. C. (1941). Cerebral manifestations of bacterial endocarditis. Annals of Internal Medicine, 14, 1551-1574.

Ziment, I. (1969). Nervous system complications in bacterial endocarditis. American Journal of Medicine, 47, 593-609.

Ziment, I., and Johnson, B. L. (1968). Angiography in the management of intracranial mycotic aneurysms. Archives of Internal Medicine, 122, 349-352. 